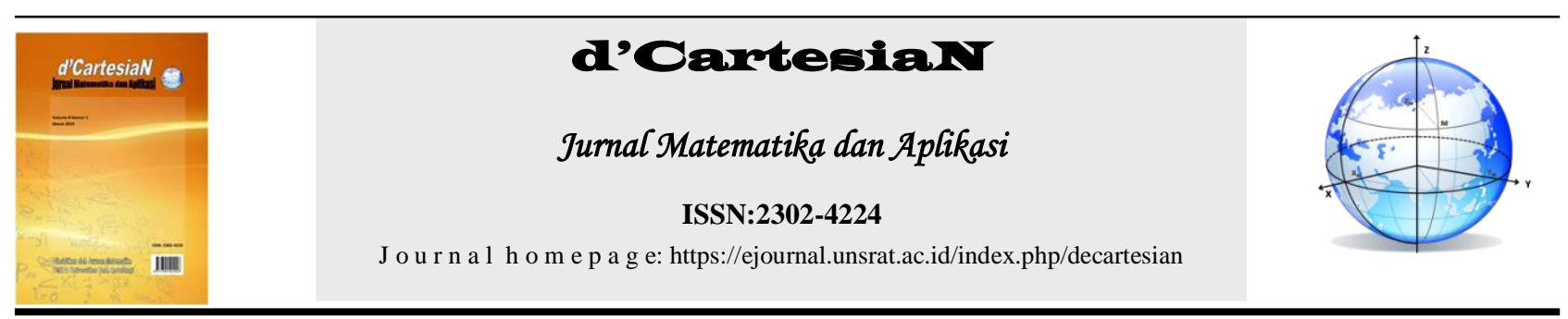

\title{
Penentuan Model Persamaan Regresi Alometrik Terbaik Untuk Menduga Biomassa Pohon Cempaka (Elmerrillia ovalis) Di Kecamatan Tareran Kabupaten Minahasa Selatan
}

\author{
Wandy Tato' Appi'1, Mans L. Mananohas', Yohanes A. R. Langi ${ }^{*}$ \\ ${ }^{1}$ Jurusan Matematika-Fakultas Matematika dan Ilmu Pengetahuan Alam-Universitas Sam Ratulangi Manado, Indonesia \\ *Corressponding author : yarlangi@gmail.com
}

\begin{abstract}
A B S T R A K
Hubungan alometrik merupakan hubungan antara suatu variabel terikat yang diduga oleh satu atau lebih variabel bebas, yang dalam hal ini diwakili oleh karakteristik yang berbeda dalam pohon. Penelitian ini bertujuan untuk menentukan persamaan regresi alometrik terbaik penduga biomassa batang dan biomassa total pohon cempaka serta menentukan besarnya potensi biomassa batang dan total pohon cempaka pada luas 1 ha. Sebanyak 20 pohon contoh dengan diameter $15-30 \mathrm{~cm}$ yang digunakan untuk menyusun persamaan regresi alometrik biomassa batang dan total pohon cempaka. Persamaan regresi alometrik terbaik penduga biomassa batang dan total pohon cempaka hanya terdiri dari satu variabel bebas yaitu variabel diameter setinggi dada (Dbh). Adapun persamaan alometriknya yaitu untuk biomassa batang: $\log B_{\mathrm{btg}}=1.5371$ + 0.721 LogDbh dan biomassa total $: \log B_{\text {tot }}=-7.08+2.391 \operatorname{LnDbh}+56.17(1 / \mathrm{Dbh})$. Besarnya potensi biomassa batang dan total pohon cempaka pada luas 1 ha dengan Dbh $18-32 \mathrm{~cm}$ sebesar $\pm 218224.472 \mathrm{~kg}$ dan $\pm 486757.831 \mathrm{~kg}$.
\end{abstract}

\section{INFO ARTIKEL}

Diterima : 8 Maret 2019

Diterima setelah revisi : 23 Maret 2019

Tersedia online : 31 Maret 2019

\section{Kata Kunci:}

Hutan Rakyat

Model Alometrik

Biomassa

Elmerrillia ovalis

\section{PENDAHULUAN}

Hutan sebagai suatu ekosistem merupakan kekayaan alam yang sangat potensial untuk digali bagi kepentingan manusia. Prinsip kelestarian hutan menjadi sesuatu yang sangat penting dalam pengusahaannya yang cenderung berskala besar. Dalam pemanfaatan hutan, aspek-aspek yang harus dipertimbangkan di antaranya : aspek lingkungan, sosial dan ekonomi. Hal yang perlu dikaji dalam pertimbangan aspek lingkungan yaitu potensi hutan melalui pendekatan besarnya biomassa pohon sebagai salah satu komponen penting dalam pengusahaan hutan.

Biomassa adalah berat bahan organik per satuan unit area pada waktu tertentu yang dinyatakan dengan istilah berat kering (dry weight) atau biomassa dapat pula diartikan sebagai berat bahan organik suatu organisme tertentu per satuan unit luas [1].

Biomassa pohon merupakan ukuran yang paling sering digunakan dalam mempelajari dan menggambarkan pertumbuhan tanaman. Hal tersebut didasarkan pada kenyataan bahwa pendugaan biomassa relatif lebih mudah diukur dan merupakan akumulasi dari total proses metabolisme yang dialami oleh tanaman.

Hampir 50\% dari biomassa hutan tersusun atas karbon [2]. Biomassa tumbuhan bertambah karena tumbuhan menyerap $\mathrm{CO}_{2}$ dari atmosfer dan mengubah senyawa tersebut menjadi bahan organik melalui proses fotosintesis [3].

Pendugaan biomassa dapat dilakukan dengan menggunakan pendekatan tanpa pemanenan (non destructive) ataupun dengan pemanenan (destructive). Menurut [4] metode paling akurat dalam pendugaan biomassa ialah melalui pendekatan pemanenan (destructive) yaitu dengan menebang pohon-pohon dan menimbang bagian-bagian pohon tersebut secara keseluruhan.

Dalam penelitian [5] tentang Model Penduga Biomassa dan Karbon pada Tegakan Hutan Rakyat Cempaka (Elmerrillia ovalis) dan Wasian (Emerrillia celebica) di Kabupaten Minahasa Sulawesi Utara dengan model persamaan alometrik terpilih untuk menduga biomassa total pohon jenis cempaka adalah $\mathrm{Y}$ $=0.064 \mathrm{D}^{2.71}$ dan jenis wasian adalah $\mathrm{Y}=0.1991 \mathrm{D}^{2.40}$.

Berhubung karena kurangnya penelitian mengenai biomassa hutan pada Hutan Rakyat Minahasa maka diperlukan penelitian-penelitian untuk mendorong kemajuan informasi mengenai kandungan biomassa hutan rakyat. Informasi kandungan biomassa ini juga akan digunakan untuk membangun model penduga biomassa pada bagian pohon yaitu: batang dan total pohon. Melalui penelitian ini, akan ditentukan model persamaan regresi alometrik terbaik untuk menduga biomassa pohon cempaka (Elmerrillia ovalis) di Kecamatan Tareran Kabupaten Minahasa Selatan. 


\subsection{Hutan Rakyat}

Hutan rakyat dalam pengertian menurut [6] adalah hutan yang tumbuh di atas tanah yang dibebani hak milik maupun hak lainnya dengan ketentuan luas minimum 0,25 ha dan penutupan tajuk tanaman kayukayuan lebih dari 50\%.

Praktek hutan rakyat di Indonesia telah lama diusahakan dengan beragam bentuk. Berdasarkan jenis tanaman dan pola penanamannya hutan rakyat dapat digolongkan ke dalam bentuk hutan rakyat murni, hutan rakyat campuran dan hutan rakyat dengan pola wanatani (agroforestry) [5].

Beberapa definisi tentang agroforestry, yaitu suatu sistem penggunaan lahan dimana (a) tanaman tahunan dan tanaman perdu tumbuh bersama-sama dalam campuran dengan pembagian tapak dan atau secara berurutan dengan atau tanpa hewan, (b) menghasilkan lebih besar keuntungan pada penggunaan lahannya daripada mengusahakan tanaman pertanian atau hutan saja [7].

Empat komponen utama sebagai ciri khas agroforestry, yaitu: (1) menghasilkan beragam keluaran yang dikombinasikan dengan perlindungan sumberdaya, (2) menggunakan jenis lokal, tumbuhan bawah dan pohon serba guna yang bertujuan agar agroforestry sesuai dengan lingkungannya, (3) lebih mengedepankan nilai- nilai sosial budaya, (4) praktek yang dilakukan lebih rumit daripada jenis monokultur [8].

\subsection{Persamaan Regresi}

Persamaan Regresi (regression equation) adalah suatu persamaan matematis yang mendefenisikan hubungan antara dua variabel.

Ada dua jenis Persamaan Regresi Linear, yaitu sebagai berikut :

1. Analisis Regresi Linear Sederhana

2. Analisis Regresi Linear Berganda

\section{Analisis Regresi Linear Sederhana}

Regresi linear sederhana merupakan suatu proses untuk mendapatkan hubungan matematis dalam bentuk suatu persamaan antara variabel tak bebas tunggal dengan variabel bebas tunggal atau dengan kata lain, regresi linear yang hanya melibatkan satu peubah bebas $\mathrm{X}$ yang dihubungkan dengan satu peubah tak bebas Y. Bentuk umum model regresi linier sederhana yaitu:

\section{dimana :}

$$
Y_{i}=\beta_{0}+\beta_{1} X_{i}+\varepsilon_{i}
$$

$$
\begin{aligned}
& \mathrm{Y}_{\mathrm{i}}=\text { nilai peubah respons dalam } \\
& \text { amatan ke-i } \\
& \beta_{0} \text { dan } \beta_{1}=\text { parameter/koefisien regresi } \\
& \mathrm{X}_{\mathrm{i}}=\text { konstanta yang diketahui } \\
& \varepsilon_{\mathrm{i}}=\text { galat yang bersifat acak }
\end{aligned}
$$

\section{Analisis Regresi Linear Berganda}

Regresi linear berganda adalah analisis regresi yang menjelaskan hubungan antara variabel terikat dengan faktor-faktor yang mempengaruhi lebih dari satu variabel bebas. [9] Bentuk umum persamaan regresi linier berganda yang mencakup dua atau lebih variabel, yaitu : dimana :
$\mathrm{Y}_{\mathrm{i}}=$ nilai peubah respons dalam amatan ke-i

$\beta_{0}, \beta_{1}, \ldots, \beta_{\mathrm{p}-1}=$ parameter $/$ koefisien regresi

$\mathrm{X}_{\mathrm{i} 1}, \ldots, \mathrm{X}_{\mathrm{i}, \mathrm{p}-1}=$ konstanta yang diketahui

$\varepsilon_{\mathrm{i}}=$ galat

$\mathrm{i}=1, \ldots, \mathrm{n}$

\subsection{Persamaan Alometrik Biomassa}

Istilah alometri (allometry) berasal dari bahasa Yunani, yaitu "allos" yang berarti "lain" dan "metron" yang berarti "ukuran" [10].

Model alometrik merupakan model yang sangat umum digunakan dalam biologi untuk menggambarkan perubahan dalam bentuk secara sistematis [11]. Alometri merupakan hubungan antara ukuran atau pertumbuhan dari salah satu komponen makhluk hidup dengan keseluruhan komponen dari makhluk hidup tersebut [12]. Alometri digunakan untuk menunjukkan adanya proporsi antara laju pertumbuhan relatif dari komponen-komponen yang berbeda dari individu pohon.

Hubungan alometrik merupakan hubungan antara suatu variabel terikat yang diduga oleh satu atau lebih variabel bebas, yang dalam hal ini diwakili oleh karakteristik yang berbeda dalam pohon. Contohnya hubungan antara volume pohon atau biomassa pohon dengan diameter dan tinggi total pohon, yang disebut sebagai variabel bebas. Hubungan ini biasanya dinyatakan dalam suatu persamaan alometrik [13].

Dari model-model yang sudah dikembangkan di Indonesia, model alometrik biomassa pohon umumnya disajikan dalam bentuk pangkat :

$$
\mathrm{Y}=\mathrm{aX} \mathrm{b}^{\mathrm{b}}
$$

dimana $\mathrm{X}=$ peubah bebas (Dbh, atau kombinasi dari Dbh dan tinggi), dan $\mathrm{Y}=$ peubah tak bebas (biomassa); $\mathrm{a}=$ koefisien model alometrik; dan $\mathrm{b}=$ exponent model alometrik.

Sebanyak $27 \%$ model disajikan dalam bentuk hubungan matematika "logaritma linear" :

$$
\log (\mathrm{Y})=\mathrm{a}+\mathrm{b}[\log (\mathrm{X})
$$

dimana $\log (\mathrm{Y})$ adalah transformasi logaritma alam (ln) atau logaritma berbasis bilangan 10 (' $\log _{10}$ ' atau bisa juga dinotasikan dengan 'log') dari data biomassa (biomassa pohon total termasuk akar, biomassa pohon total bagian atas permukaan tanah, maupun biomassa setiap komponen atau bagian pohon secara terpisah), $\log (\mathrm{X})$ adalah Dbh (baik transformasi logaritma alam (ln) ataupun logaritma berbasis bilangan 10 (log)), sedangkan a dan b merupakan koefisien regresi [14].

\section{METODE PENELITIAN}

\section{Waktu dan Tempat Penelitian}

Penelitian ini dilaksanakan pada bulan November 2018 - Maret 2019, bertempat di tegakan hutan rakyat Tareran, Minahasa Selatan. Selanjutnya pengelolaan data dilakukan di Laboratorium Statistika Jurusan Matematika, FMIPA UNSRAT.

\section{Teknik Pengambilan Sampe}

Populasi dalam penelitian ini adalah tegakan pohon cempaka pada hutan rakyat di Kecamatan Tareran, Kabupaten Minahasa Selatan. Teknik sampling yang digunakan yaitu stratified random sampling. Sebanyak 20 pohon contoh terpilih untuk ditebang. 


\section{Penentuan Model Persamaan Regresi Alometrik Terbaik Untuk Menduga Biomassa Pohon Cempaka (Elmerrillia ovalis) Di Kecamatan Tareran Kabupaten Minahasa Selatan \\ d’Cartesian : Jurnal Matematika dan Aplikasi, Vol. 8, No. 1 (Maret 2019) : 69 - 75}

\section{Alat Penelitian}

Alat-alat yang digunakan dalam penelitian ini adalah pita ukur, haga hypsometer dan meteran.

\section{Variabel Penelitian}

Variabel-variabel yang digunakan dalam penelitian ini adalah sebagai berikut :

Variabel 1 = biomassa pohon $(\mathrm{kg})$

Variabel 2 diameter pohon setinggi dada $(\mathrm{cm})$

Variabel 3 = tinggi pohon $(\mathrm{cm})$

Variabel 4 = luas bidang dasar/basal area $(\mathrm{cm})$

Variabel $5=$ berat jenis pohon

\section{Sumber Data}

Sumber data dalam penelitian ini adalah data primer yang diukur secara langsung di lapangan. Data primer meliputi : diameter pohon setinggi dada (dbh), tinggi total pohon $\left(\mathrm{H}_{\text {tot }}\right)$, tinggi bebas cabang pohon $\left(\mathrm{H}_{\mathrm{bc}}\right)$, luas bidang dasar atau basal area (Lbds) dan berat jenis pohon (BJ).

\section{Pengolahan dan Analisis Data}

\section{Penyusunan Persamaan Alometrik Penduga Biomassa}

Biomassa pohon dalam penelitian ini dikelompokkan menjadi biomassa batang dan biomassa total. Untuk tujuan pendugaan biomassanya maka dilakukan penyusunan model penduga biomassa yang terdiri dari model penduga biomassa batang dan model penduga biomassa total. Model yang diujicobakan terdiri dari berbagai model dengan menggunakan satu atau lebih variabel bebas. Variabel bebas yang digunakan yaitu : diameter setingggi dada (dbh), tinggi pohon, luas bidang dasar dan berat jenis pohon.

\section{Pemilihan Model Terbaik}

Pemilihan model terbaik didasarkan pada :

$>$ Koefisien Determinasi $\left(\mathrm{R}^{2}\right)$

$>$ Simpangan Baku

> Koefisien Determinasi Terkoreksi ( $\mathrm{R}^{2}$ adj $)$

$>$ Nilai PRESS

$>$ Nilai Fhitung

\section{Uji Keabsahan Model}

Uji keabsahan model (Model Validation) bertujuan untuk melihat kemampuan model dalam menduga sekelompok data baru (yang tidak diikutsertakan dalam pembentukan modelnya

\section{HASIL DAN PEMBAHASAN}

\subsection{Deskripsi Data}

\section{Penyebaran Pohon Contoh Menurut Diameter} Pohon

Pohon contoh dipilih berdasarkan keterwakilan kelas diameter yang ada di lokasi penelitian. Pohon cempaka didominasi oleh pohon-pohon dengan kelas diameter antara $20-30 \mathrm{~cm}$. Penyebaran data pohon contoh berdasarkan kelas diameter dan tinggi totalnya disajikan pada Tabel 1.
Tabel 1 Sebaran Data Pohon Contoh Cempaka Menurut Diameter Dan Tinggi Total

\begin{tabular}{ccccc}
\hline \multirow{2}{*}{$\begin{array}{c}\text { Diameter } \\
(\mathrm{Cm})\end{array}$} & \multicolumn{3}{c}{ Tinggi Total (m) } & Jumlah \\
\cline { 2 - 4 } & $\begin{array}{c}15.0- \\
19.9\end{array}$ & $\begin{array}{c}20.0- \\
24.9\end{array}$ & $\begin{array}{c}25.0- \\
29.9\end{array}$ & \\
\hline $20-30$ & 1 & 14 & - & 15 \\
$31-40$ & - & - & 5 & 5 \\
\hline Jumlah & 1 & 14 & 5 & 20 \\
\hline
\end{tabular}

\section{Biomassa Pohon-Pohon Contoh}

Dalam penelitian ini, kecenderungan nilai biomassa meningkat seiring dengan bertambahnya ukuran diameter pohon. Ketika ukuran pohon semakin besar maka biomassa dari pohon tersebut juga akan besar

\subsection{Persamaan Alometrik Pohon}

\section{Persamaan Alometrik Penduga Biomassa} Batang

Persamaan alometrik penduga biomassa batang yang terbaik ditentukan melalui uji coba terhadap beberapa persamaan regresi linear maupun non linear baik dengan satu atau lebih peubah bebas. Model persamaan alometrik untuk 20 pohon contoh dalam penelitian ini dapat diamati pada Tabel 2.

Tabel 2 Persamaan Alometrik Penduga Biomassa Batang untuk 20 Pohon Contoh Cempaka

\begin{tabular}{|c|c|c|c|c|c|c|}
\hline No & Persamaan & $\mathrm{s}$ & $\begin{array}{c}\mathrm{R}^{2} \\
(\%)\end{array}$ & $\begin{array}{l}\mathrm{R}^{2} \text { adj } \\
(\%)\end{array}$ & PRESS & F hitung \\
\hline 1 & $\begin{array}{l}\text { B_Btg }=135.8 \\
+10.28 \mathrm{Dbh}+ \\
0.28 \mathrm{H}-0.353 \\
\text { lbds - 53 BJ }\end{array}$ & 14.947 & $93 \cdot 3$ & 91.52 & 525199 & 52.25 \\
\hline 2 & $\begin{array}{l}\text { B_Btg = 149.7 } \\
+10.48 \mathrm{Dbh}- \\
1.40 \mathrm{H}-0.358 \\
\text { Lbds }\end{array}$ & 14.56 & 93.22 & 91.95 & 459292 & 73.35 \\
\hline 3 & $\begin{array}{l}\text { B_Btg = 126.5 } \\
+9.74 \text { Dbh - } \\
\text { o.82 H } \\
\text { B_Btg }=127.9\end{array}$ & 16.19 & 91.09 & 90.05 & 6272.06 & 86.93 \\
\hline 4 & $\begin{array}{l}+10.083 \mathrm{Dbh}- \\
\text { O.351 Lbds } \\
\text { B Btg }=123.9\end{array}$ & 14.22 & 93.13 & 92.33 & 164.753 & 115.29 \\
\hline 5 & $\begin{array}{l}+9.739 \mathrm{Dbh}- \\
43.5 \mathrm{BJ}\end{array}$ & 16.09 & 91.21 & 90.17 & 6085.19 & 88.15 \\
\hline 6 & $\begin{array}{l}\text { Log B_Btg = } \\
1.578+0.7582 \\
\text { Log Dbh - } \\
\text { o.031 Log H - } \\
\text { o.0385 Log } \\
\text { Lbds - o.05o } \\
\text { Log BJ }\end{array}$ & 0.016 & 93.16 & 91.33 & 0.263 & 51.04 \\
\hline 7 & $\begin{array}{l}\text { Log B_Btg = } \\
1.713+0.7716 \\
\text { Log Dbh - } \\
\text { o.127 Log H - } \\
\text { o.039o Log } \\
\text { Lbds }\end{array}$ & 0.016 & 93.06 & 91.76 & 0.217 & 71.53 \\
\hline 8 & $\begin{array}{l}\text { Log B_Btg }= \\
1.623+0.7579 \\
\text { Log Dbh - } \\
\text { o.102 Log H }\end{array}$ & 0.017 & 91.47 & 90.47 & 0.007 & 91.17 \\
\hline 9 & $\begin{array}{l}\text { Log B_Btg }= \\
1.6034+ \\
\text { o.7254 Log } \\
\text { Dbh - o.o378 } \\
\text { Log Lbds }\end{array}$ & 0.016 & 92.83 & 91.98 & 1.705 & 109.98 \\
\hline 10 & $\begin{array}{l}\text { Log B_Btg = } \\
1.478+0.7454 \\
\text { Log Dbh - } \\
\text { o.0561 Log BJ }\end{array}$ & 0.017 & 91.61 & 90.62 & 0.007 & 92.83 \\
\hline
\end{tabular}

Berdasarkan kriteria statistik dari Tabel 2 dapat diamati bahwa persamaan $\log B \_B t g=1.623+0.7579$ Log Dbh - 0.102 Log H merupakan persamaan terbaik. Ketepatan dari sebuah model untuk menduga dapat diperlihatkan dengan melakukan uji validasi persamaan alometrik biomassa pohon cempaka. Dari pengujian validasi model terpilih didapatkan nilai $\bar{d}$ dan $C V_{d}$ yaitu 
sebesar 0.03 dan 1.2 yang berarti model yang terpilih dapat menduga sekelompok data yang baru.

Model yang terpilih kemudian dibandingkan dengan model-model alometrik lain dari berbagai referensi dapat diamati pada Tabel 3 .

Tabel 3 Persamaan Alometrik Penduga Biomassa Batang Pohon dari Berbagai Referensi

\begin{tabular}{|c|c|c|c|c|c|c|}
\hline Model & Persamaan & $\mathrm{s}$ & $\begin{array}{l}\mathrm{R}^{2} \\
(\%)\end{array}$ & $\begin{array}{l}\mathrm{R}^{2} \text { adj } \\
(\%)\end{array}$ & PRESS & $F_{\text {hitung }}$ \\
\hline $\begin{array}{l}\text { Berkho } \\
\text { ut }\end{array}$ & $\begin{array}{l}\text { B_Btg }=113.9 \\
+9.513 \mathrm{Dbh}\end{array}$ & $\begin{array}{c}15.76 \\
3\end{array}$ & $\begin{array}{c}91.0 \\
6\end{array}$ & $\begin{array}{c}90.5 \\
7\end{array}$ & 5799.8 & $\begin{array}{c}183.4 \\
1\end{array}$ \\
\hline $\begin{array}{l}\text { Spurr } \\
(1952)\end{array}$ & $\begin{array}{l}\text { B_Btg = } \\
260.5+ \\
0.1497 \mathrm{Dbh}^{2}\end{array}$ & $\begin{array}{c}16.9 \\
27\end{array}$ & $\begin{array}{c}89.6 \\
9\end{array}$ & $\begin{array}{c}89.1 \\
2\end{array}$ & $\begin{array}{c}6734.9 \\
9\end{array}$ & $\begin{array}{c}156.6 \\
5\end{array}$ \\
\hline $\begin{array}{l}\text { Spurr. } \\
\text { Mod } \\
(1952)\end{array}$ & $\begin{array}{l}\text { B_Btg }=257.5 \\
+0.1491 \mathrm{Dbh}^{2} \\
+0.15 \mathrm{H}\end{array}$ & $\begin{array}{c}17.41 \\
7\end{array}$ & $\begin{array}{c}89.6 \\
9\end{array}$ & $\begin{array}{c}88.4 \\
8\end{array}$ & 7433.14 & 73.98 \\
\hline Stoate & $\begin{array}{l}\text { B_Btg }=120 \\
+0.347 \mathrm{Dbh}^{2} \\
- \\
\mathrm{O} .00770 \mathrm{Dbh}^{2} \\
\mathrm{H}+5.49 \mathrm{H}\end{array}$ & $\begin{array}{c}17.51 \\
2\end{array}$ & $\begin{array}{c}90.2 \\
0\end{array}$ & $\begin{array}{c}88.3 \\
6\end{array}$ & $\begin{array}{c}7573.8 \\
6\end{array}$ & 49.06 \\
\hline $\begin{array}{l}\text { Hohen } \\
\text { adl- } \\
\text { Krenn }\end{array}$ & $\begin{array}{l}\text { B_Btg }=26+ \\
15.27 \mathrm{Dbh}- \\
0.092 \mathrm{Dbh}^{2}\end{array}$ & $\begin{array}{c}16.01 \\
0\end{array}$ & $\begin{array}{c}91.2 \\
9\end{array}$ & $\begin{array}{c}90.2 \\
7\end{array}$ & $\begin{array}{c}6051.5 \\
8\end{array}$ & 89.11 \\
\hline $\begin{array}{l}\text { Meyer } \\
(1953)\end{array}$ & $\begin{array}{l}\text { B_Btg }=441 \\
+8.4 \mathrm{Dbh}^{-} \\
0.364 \mathrm{Dbh}^{2}+ \\
0.965 \mathrm{DbhH}- \\
27.4 \mathrm{H}\end{array}$ & $\begin{array}{c}16.2 \\
89\end{array}$ & $\begin{array}{c}92.0 \\
5\end{array}$ & $\begin{array}{c}89.9 \\
3\end{array}$ & 8457.18 & 43.40 \\
\hline $\begin{array}{l}\text { Meyer. } \\
\text { Mod } \\
(1953)\end{array}$ & $\begin{array}{l}\text { B_Btg }=-273 \\
+62.9 \mathrm{Dbh}^{-} \\
1.38 \mathrm{Dbh}^{2}+ \\
0.0391 \mathrm{Dbh}^{2} \mathrm{H} \\
-1.13 \mathrm{DbhH}\end{array}$ & $\begin{array}{c}16.36 \\
5\end{array}$ & $\begin{array}{c}91.9 \\
7\end{array}$ & $\begin{array}{c}89.8 \\
3\end{array}$ & $\begin{array}{c}7762.8 \\
8\end{array}$ & 42.96 \\
\hline Brenac & $\begin{array}{l}\text { LogB_Btg }= \\
1.66+ \\
0.286 \operatorname{LnDbh} \\
- \\
0.82(1 / \mathrm{Dbh})\end{array}$ & $\begin{array}{c}0.01 \\
7\end{array}$ & $\begin{array}{c}91.3 \\
3\end{array}$ & $\begin{array}{c}90.3 \\
1\end{array}$ & 0.0067 & 88.28 \\
\hline $\begin{array}{l}\text { Jenkin } \\
\text { s et al. } \\
(2003)\end{array}$ & $\begin{array}{l}\text { LnB_Btg = } \\
3.539+ \\
0.7211 \operatorname{LnDbh}\end{array}$ & $\begin{array}{c}0.03 \\
8\end{array}$ & $\begin{array}{c}91.3 \\
2\end{array}$ & $\begin{array}{c}90.8 \\
4\end{array}$ & 0.0333 & $\begin{array}{c}189.3 \\
9\end{array}$ \\
\hline $\begin{array}{l}\text { Langi } \\
(2007)\end{array}$ & $\begin{array}{l}\text { LogB_Btg }= \\
1.5371+ \\
0.7211 \log D b h\end{array}$ & $\begin{array}{c}0.01 \\
7\end{array}$ & $\begin{array}{c}91.3 \\
2\end{array}$ & $\begin{array}{c}90.8 \\
4\end{array}$ & 0.0063 & $\begin{array}{c}189.3 \\
9\end{array}$ \\
\hline $\begin{array}{l}\text { This } \\
\text { Study } 1\end{array}$ & $\begin{array}{l}\text { LogB_Btg = } \\
1.6034+ \\
\text { o.7254LogDb } \\
\text { h- } \\
\text { o.o378LogLb } \\
\text { ds } \\
\text { LogB_Batang }\end{array}$ & $\begin{array}{c}0.01 \\
6\end{array}$ & $\begin{array}{c}92.8 \\
3\end{array}$ & $\begin{array}{c}91.9 \\
8\end{array}$ & 1.705 & $\begin{array}{c}109.9 \\
8\end{array}$ \\
\hline $\begin{array}{l}\text { This } \\
\text { Study } \\
2\end{array}$ & $\begin{array}{l}=1.623+ \\
0.7579 \log \mathrm{Db} \\
\mathrm{h}- \\
0.102 \log \mathrm{H}\end{array}$ & $\begin{array}{c}0.01 \\
7\end{array}$ & $\begin{array}{c}91.4 \\
7\end{array}$ & $\begin{array}{c}90.4 \\
7\end{array}$ & 0.0067 & 91.17 \\
\hline
\end{tabular}

Sumber : [15] B_Btg = Biomassa Batang (kg), Dbh = Diameter setinggi dada $(\mathrm{cm}), \mathrm{H}=$ Tinggi total $(\mathrm{m})$, Lbds $=$ Luas bidang dasar $\left(\mathrm{m}^{2}\right)$

Pemilihan model persamaan alometrik terbaik dilakukan dengan melakukan uji terhadap nilai-nilai regresi persamaan tersebut. Pemilihan model persamaan alometrik biomassa terbaik berdasarkan nilai statistik yang ditunjukkan pada Tabel 3 dilakukan pengurutan performansi untuk setiap persamaan berdasarkan persamaan yang mempunyai nilai simpangan baku (s) dan statistik PRESS terkecil sedangkan nilai $\mathrm{R}^{2}$ adjusted dan Fhitung terbesar. Hasil pengurutan terhadap keempat kriteria ini dapat dilihat pada Tabel 4 .
Tabel 4 Urutan Performansi Persamaan Alometrik Penduga Biomassa Batang

\begin{tabular}{|c|c|c|c|c|c|c|}
\hline \multirow{2}{*}{ Persamaan } & \multicolumn{4}{|c|}{ Kriteria } & \multirow[b]{2}{*}{ Total } & \multirow{2}{*}{ Rank } \\
\hline & $\mathrm{s}$ & $\begin{array}{l}\mathrm{R}^{2} \text { adj } \\
(\%)\end{array}$ & PRESS & $F_{\text {hitung }}$ & & \\
\hline $\begin{array}{l}\text { B_Btg = 113.9 + } \\
9.513 \mathrm{Dbh}\end{array}$ & 4 & 3 & 5 & 2 & 14 & 5 \\
\hline $\begin{array}{l}\text { B_Btg }=260.5+ \\
0.1497 \mathrm{Dbh}^{2}\end{array}$ & 8 & 9 & 7 & 3 & 27 & 8 \\
\hline $\begin{array}{l}\text { B_Btg }=257.5+ \\
0.1491 \mathrm{Dbh}^{2}+0.15 \mathrm{H}\end{array}$ & 9 & 10 & 8 & 8 & 35 & 10 \\
\hline $\begin{array}{l}\text { B_Btg }=120+ \\
0.347 \mathrm{Dbh}^{2}- \\
0.0077 \mathrm{ODbh}^{2} \mathrm{H}+ \\
5.49 \mathrm{H}\end{array}$ & 10 & 11 & 9 & 9 & 39 & 12 \\
\hline $\begin{array}{l}\text { B_Btg }=26+ \\
15.27 \mathrm{Dbh}^{-} \\
0.092 \mathrm{Dbh}^{2}\end{array}$ & 5 & 6 & 6 & 6 & 23 & 7 \\
\hline $\begin{array}{l}\text { B_Btg }=441+ \\
8.4 \mathrm{Dbh}- \\
0.364 \mathrm{Dbh}^{2}+ \\
0.965 \mathrm{DbhH}^{-27.4 \mathrm{H}}\end{array}$ & 6 & 7 & 11 & 10 & 34 & 9 \\
\hline $\begin{array}{l}\text { B_Btg }=-273+ \\
\text { 62.9Dbh }-1.38 \mathrm{Dbh}^{2} \\
+ \text { o.0391Dbh }{ }^{2} \mathrm{H}- \\
\text { 1.13DbhH }\end{array}$ & 7 & 8 & 10 & 11 & 36 & 11 \\
\hline $\begin{array}{l}\log B \_B t g=1.66+ \\
0.286 \operatorname{LnDbh}- \\
0.82(1 / \mathrm{Dbh})\end{array}$ & 2 & 5 & 2 & 7 & 16 & 6 \\
\hline $\begin{array}{l}\operatorname{LnB} \_ \text {Btg }=3.539+ \\
\text { o.7211LnDbh }\end{array}$ & 3 & 2 & 3 & 1 & 9 & 2 \\
\hline $\begin{array}{l}\text { LogB_Btg }=1.5371 \\
+0.7211 \operatorname{LogDbh}\end{array}$ & 2 & 2 & 1 & 1 & 6 & 1 \\
\hline $\begin{array}{l}\text { LogB_Btg = 1.6034 } \\
\text { + 0.7254LogDbh - } \\
\text { o.0378LogLbds }\end{array}$ & 1 & 1 & 4 & 4 & 10 & 3 \\
\hline $\begin{array}{l}\text { LogB_Btg }=1.623+ \\
\text { o.7579LogDBH }- \\
0.102 \operatorname{LogH}\end{array}$ & 2 & 4 & 2 & 5 & 13 & 4 \\
\hline
\end{tabular}

Berdasarkan kriteria statistik dari Tabel 3 dapat diamati bahwa persamaan LogB_Btg $=1.5371+$ o.7211LogDbh mempunyai performansi yang paling baik.

\section{Persamaan Alometrik Penduga Biomassa Total}

Biomassa total pohon di atas tanah merupakan akumulasi dari biomassa batang, biomassa cabang, biomassa ranting, biomassa daun dan biomassa buah pohon cempaka. Pendugaan biomassa total pohon cempaka dilakukan dengan membentuk sebuah model penduga biomassa total pohon bagian atas tanah dengan peubah-peubah seperti diameter setinggi dada (Dbh), tinggi pohon $\left(\mathrm{H}_{\text {tot }}\right.$ dan $\left.\mathrm{H}_{\mathrm{bc}}\right)$, luas bidang dasar (Lbds). Model persamaan alometrik untuk 20 pohon contoh dalam penelitian ini dapat diamati pada Tabel 5 .

Tabel 5 Persamaan Alometrik Penduga Biomassa Total untuk 20 Pohon Contoh Cempaka

\begin{tabular}{|c|c|c|c|c|c|c|}
\hline No & Persamaan & $\mathrm{s}$ & $\begin{array}{l}\mathrm{R}^{2} \\
(\%)\end{array}$ & $\begin{array}{l}\mathrm{R}^{2} \text { adj } \\
(\%)\end{array}$ & PRESS & $\mathrm{F}$ \\
\hline 1 & $\begin{array}{l}\text { B_Tot }=-251 \\
+40.08 \mathrm{Dbh} \\
-2.6 \mathrm{H}+0.8 \\
\text { Lbds }-167 \\
\text { BJ }\end{array}$ & 94.826 & 85.64 & 81.81 & 658611643 & 22.36 \\
\hline 2 & $\begin{array}{l}\text { B_Tot }=- \\
207+40.71\end{array}$ & 91.954 & 85.59 & 82.89 & 664397320 & 31.69 \\
\hline
\end{tabular}


Penentuan Model Persamaan Regresi Alometrik Terbaik Untuk Menduga Biomassa Pohon Cempaka (Elmerrillia ovalis) Di Kecamatan Tareran Kabupaten Minahasa Selatan

d'Cartesian : Jurnal Matematika dan Aplikasi, Vol. 8, No. 1 (Maret 2019) : 69 - 75

\begin{tabular}{|c|c|c|c|c|c|c|}
\hline No & Persamaan & $\mathrm{s}$ & $\begin{array}{l}\mathrm{R}^{2} \\
(\%)\end{array}$ & $\begin{array}{l}\mathrm{R}^{2} \text { adj } \\
(\%)\end{array}$ & PRESS & $\mathrm{F}$ \\
\hline & $\begin{array}{l}\text { Dbh }-8 \mathrm{H}+ \\
0.78 \mathrm{Lbds} \\
\text { B Tot }=-156\end{array}$ & & & & & \\
\hline 3 & $\begin{array}{l}+42.34 \mathrm{Dbh} \\
-9.2 \mathrm{H} \\
\text { B Tot }=-331\end{array}$ & 90.876 & 85.05 & 83.29 & 256458 & 72.69 \\
\hline 4 & $\begin{array}{l}+38.45 \text { Dbh } \\
+0.818 \text { Lbds }\end{array}$ & 89.676 & 85.44 & 83.77 & 689805718 & 49.89 \\
\hline 5 & $\begin{array}{l}\text { B_Tot }=- \\
246+40.95 \\
\text { Dbh }-226 \\
\text { BJ }\end{array}$ & 90.88 & 85.05 & 83.29 & 240980 & 48.35 \\
\hline 6 & $\begin{array}{l}\text { Log B_Tot = } \\
\text { 0.967+ } \\
1.201 \text { Log } \\
\text { Dbh + 0.094 } \\
\text { Log H + } \\
\text { O.0179 Log } \\
\text { Lbds - O.101 } \\
\text { Log BJ }\end{array}$ & 0.036 & 87.2 & 83.79 & 346.302 & $25 \cdot 54$ \\
\hline 7 & $\begin{array}{l}\text { Log B_Tot }= \\
1.241+1.228 \\
\text { Log Dbh - } \\
\text { 0.102 Log H } \\
+0.0168 \\
\text { Log Lbds }\end{array}$ & 0.037 & 87.06 & 84.64 & 342.491 & 35.9 \\
\hline 8 & $\begin{array}{l}\text { Log B_Tot }= \\
1.279+1.234 \\
\text { Log Dbh - } \\
\text { o.113 Log H }\end{array}$ & 0.036 & 86.96 & 85.43 & 0.038 & 56.69 \\
\hline 9 & $\begin{array}{l}\text { Log B_Tot = } \\
1.153+1.191 \\
\text { Log Dbh + } \\
\text { o.0177 Log } \\
\text { Lbds }\end{array}$ & 0.036 & 87.01 & 85.48 & 333.844 & 56.95 \\
\hline 10 & $\begin{array}{l}\text { Log B_Tot = } \\
1.107+1.225 \\
\text { Log Dbh - } \\
\text { O.074 Log } \\
\text { BJ }\end{array}$ & 0.035 & 87.07 & 85.55 & 0.034 & 57.25 \\
\hline
\end{tabular}

Berdasarkan kriteria statistik dari Tabel 5 dapat diamati bahwa persamaan LogB_Tot $=1.279+1.234$ Log Dbh - o.113 Log H merupakan persamaan terbaik. Ketepatan dari sebuah model untuk menduga dapat diperlihatkan dengan melakukan uji validasi persamaan alometrik biomassa total pohon cempaka. Dari pengujian validasi model terpilih didapatkan nilai $\bar{d}$ dan $C V_{d}$ yaitu sebesar 0.08 dan 1.1 yang berarti model yang terpilih dapat menduga sekelompok data yang baru.

Model yang terpilih kemudian dibandingkan dengan model-model alometrik lain dari berbagai referensi dapat diamati pada Tabel 6 .

Tabel 6 Persamaan Alometrik Penduga Biomassa Total Pohon dari Berbagai Referensi

\begin{tabular}{|c|c|c|c|c|c|c|}
\hline Model & Persamaan & $\mathrm{S}$ & $\begin{array}{l}\mathrm{R}^{2} \\
(\%)\end{array}$ & $\begin{array}{l}\mathrm{R}^{2} \text { adj } \\
(\%)\end{array}$ & PRESS & $F_{\text {hitung }}$ \\
\hline Berkhout & $\begin{array}{l}\text { B_Tot }=- \\
298 \\
+39.78 \mathrm{Db} \\
\mathrm{h} \\
\text { B_Btg }=\end{array}$ & $\begin{array}{l}88 . \\
920\end{array}$ & $\begin{array}{c}84.8 \\
5\end{array}$ & 84 & 230574 & $\begin{array}{c}100.7 \\
8\end{array}$ \\
\hline $\begin{array}{l}\text { Spurr } \\
(1952)\end{array}$ & $\begin{array}{l}295.7+ \\
0.6472 \mathrm{Dbh}\end{array}$ & $\begin{array}{c}74.7 \\
63\end{array}$ & $\begin{array}{c}89.2 \\
9\end{array}$ & $\begin{array}{c}88.6 \\
9\end{array}$ & 172288 & $\begin{array}{c}150.0 \\
2\end{array}$ \\
\hline $\begin{array}{l}\text { Spurr. } \\
\text { Mod } \\
(1952)\end{array}$ & $\begin{array}{l}\text { B_Btg }= \\
549+ \\
0.7033 \mathrm{Dbh} \\
2-12.9 \mathrm{H}\end{array}$ & $\begin{array}{c}75 \cdot 4 \\
39\end{array}$ & $\begin{array}{c}89.7 \\
0\end{array}$ & $\begin{array}{c}88.4 \\
9\end{array}$ & 183846 & 74.01 \\
\hline Stoate & $\begin{array}{l}\text { B_Tot }= \\
2100- \\
1.532 \mathrm{Dbh}^{2} \\
+ \\
\text { O.0871Dbh } \\
{ }^{2} \mathrm{H}-73.3 \mathrm{H}\end{array}$ & $\begin{array}{l}63 . \\
572\end{array}$ & 93.11 & 91.82 & 183969 & 72.13 \\
\hline
\end{tabular}

\begin{tabular}{|c|c|c|c|c|c|c|}
\hline Model & Persamaan & $\mathrm{s}$ & $\begin{array}{l}\mathrm{R}^{2} \\
(\%)\end{array}$ & $\begin{array}{l}\mathrm{R}^{2} \text { adj } \\
(\%)\end{array}$ & PRESS & $F_{\text {hitung }}$ \\
\hline $\begin{array}{l}\text { Hohenad } \\
\text { l-Krenn }\end{array}$ & $\begin{array}{l}\text { B_Tot }= \\
2299- \\
130.5 \mathrm{Dbh} \\
+ \\
2.710 \mathrm{Dbh}^{2}\end{array}$ & $\begin{array}{l}49 . \\
837\end{array}$ & $\begin{array}{l}95 \cdot 5 \\
0\end{array}$ & $\begin{array}{c}94.9 \\
8\end{array}$ & $\begin{array}{c}93005 \\
3\end{array}$ & $\begin{array}{c}180.5 \\
6\end{array}$ \\
\hline $\begin{array}{l}\text { Meyer } \\
(1953)\end{array}$ & $\begin{array}{l}\text { B_Tot }= \\
1128- \\
106.8 \mathrm{Dbh} \\
+ \\
3.505 \mathrm{Dbh}^{2} \\
- \\
2.89 \mathrm{DbhH} \\
+76.1 \mathrm{H}\end{array}$ & $\begin{array}{l}50 . \\
862\end{array}$ & 95.87 & 94.77 & 125390 & 87.01 \\
\hline $\begin{array}{l}\text { Meyer.M } \\
\text { od (1953) }\end{array}$ & $\begin{array}{l}\text { B_Tot }= \\
2888- \\
223 \mathrm{Dbh}^{-} \\
5 \cdot 37 \mathrm{Dbh}^{2}- \\
\text { O.o8oDbh } \\
\mathrm{H}+ \\
2.09 \mathrm{DbhH}\end{array}$ & $\begin{array}{c}51.8 \\
19\end{array}$ & $95 \cdot 71$ & 94.57 & 138476 & 83.69 \\
\hline Brenac & $\begin{array}{l}\text { LogB_Tot } \\
=-7.08+ \\
2.391 \operatorname{LnDb} \\
\mathrm{h}+ \\
56.17(1 / \mathrm{Db} \\
\text { h) }\end{array}$ & $\begin{array}{c}0.0 \\
20\end{array}$ & $\begin{array}{l}95.6 \\
8\end{array}$ & 95.17 & 0.0128 & $\begin{array}{c}188.2 \\
0\end{array}$ \\
\hline $\begin{array}{l}\text { Jenkins } \\
\text { et al. } \\
(2003)\end{array}$ & $\begin{array}{l}\text { LnB_Tot = } \\
2.728+ \\
1.193 \operatorname{LnDb} \\
\mathrm{h}\end{array}$ & $\begin{array}{l}0.0 \\
80\end{array}$ & 86.9 & 86.17 & 0.1713 & $\begin{array}{c}119.3 \\
8\end{array}$ \\
\hline $\begin{array}{l}\text { Langi } \\
(2007)\end{array}$ & $\begin{array}{l}\text { LogB_Tot } \\
=1.185^{+} \\
1.193 \log \mathrm{D} \\
\text { bh }\end{array}$ & $\begin{array}{l}0.0 \\
35\end{array}$ & $\begin{array}{c}86.9 \\
0\end{array}$ & 86.17 & 0.0323 & $\begin{array}{c}119.3 \\
8\end{array}$ \\
\hline $\begin{array}{l}\text { This } \\
\text { Study } 1\end{array}$ & $\begin{array}{l}\text { LogB_Tot } \\
=1.153+ \\
1.191 \operatorname{LogDb} \\
\mathrm{h}+ \\
\text { o.0177Log } \\
\text { Lbds }\end{array}$ & $\begin{array}{l}0.0 \\
36\end{array}$ & 87.01 & $\begin{array}{c}85.4 \\
8\end{array}$ & $\begin{array}{c}333.84 \\
4\end{array}$ & 56.95 \\
\hline $\begin{array}{l}\text { This } \\
\text { Study } 2\end{array}$ & $\begin{array}{l}\text { LogB_Tot } \\
=1.279+ \\
1.234 \log \mathrm{D} \\
\text { bh - } \\
\text { o.113LogH }\end{array}$ & $\begin{array}{l}0.0 \\
36\end{array}$ & $\begin{array}{c}86.9 \\
6\end{array}$ & $\begin{array}{c}85.4 \\
3\end{array}$ & 0.038 & 56.69 \\
\hline
\end{tabular}

Sumber : [15] B_BTot = Biomassa Total $(\mathrm{kg})$, Dbh $=$ Diameter setinggi dada $(\mathrm{cm}), \mathrm{H}=$ Tinggi total $(\mathrm{m})$, Lbds $=$ Luas bidang dasar $\left(\mathrm{m}^{2}\right)$

Penentuan persamaan penduga biomassa total pohon cempaka dapat ditentukan dengan performansi terbaik dengan kriteria nilai uji statistik yang tertera pada Tabel 6. Pengurutan performansi untuk persamaan terbaik dapat dilihat pada Tabel 7.

Tabel 7 Urutan Performansi Persamaan Alometrik Penduga Biomassa Total

\begin{tabular}{|c|c|c|c|c|c|c|}
\hline \multirow{2}{*}{ Persamaan } & \multicolumn{4}{|c|}{ Kriteria } & \multirow{2}{*}{ Total } & \multirow{2}{*}{ Rank } \\
\hline & $\mathrm{s}$ & $\mathrm{R}^{2}$ adj $(\%)$ & PRESS & $F_{\text {hitung }}$ & & \\
\hline $\begin{array}{l}\text { B_Tot }=-298 \\
+39.78 \mathrm{Dbh}\end{array}$ & 11 & 11 & 12 & 5 & 39 & 10 \\
\hline $\begin{array}{l}\text { B_Btg }=295.7 \\
+0.6472 \mathrm{Dbh}^{2}\end{array}$ & 9 & 6 & 9 & 3 & 27 & 7 \\
\hline $\begin{array}{l}\text { B_Btg }=549+ \\
0.7033 \mathrm{Dbh}^{2}- \\
12.9 \mathrm{H}\end{array}$ & 10 & 7 & 10 & 8 & 35 & 9 \\
\hline $\begin{array}{l}\text { B_Tot }=2100- \\
1.532 \mathrm{Dbh}^{2}+ \\
0.0871 \mathrm{Dbh}^{2} \mathrm{H}- \\
73.3 \mathrm{H}\end{array}$ & 8 & 5 & 11 & 9 & 33 & 8 \\
\hline
\end{tabular}




\begin{tabular}{|c|c|c|c|c|c|c|}
\hline \multirow{2}{*}{ Persamaan } & \multicolumn{4}{|c|}{ Kriteria } & \multirow{2}{*}{ Total } & \multirow{2}{*}{ Rank } \\
\hline & $\mathrm{s}$ & $\mathrm{R}^{2}$ adj $(\%)$ & PRESS & $F_{\text {hitung }}$ & & \\
\hline $\begin{array}{l}\text { B_Tot }=2299- \\
130.5 \mathrm{Dbh}+ \\
2.710 \mathrm{Dbh}^{2}\end{array}$ & 5 & 2 & 6 & 2 & 15 & 2 \\
\hline $\begin{array}{l}\text { B_Tot }=1128- \\
106.8 \mathrm{Dbh}^{2} \\
3.505 \mathrm{Dbh}^{2}- \\
2.89 \mathrm{DbhH}+ \\
76.1 \mathrm{H}\end{array}$ & 6 & 3 & 7 & 6 & 22 & 5 \\
\hline $\begin{array}{l}\text { B_Tot }=2888- \\
223 \mathrm{Dbh}- \\
5.37 \mathrm{Dbh}^{2}- \\
\text { 0.08oDbh } \\
\text { 2.09DbhH }+\end{array}$ & 7 & 4 & 8 & 7 & 26 & 6 \\
\hline $\begin{array}{l}\text { LogB_Tot }=- \\
7.08+ \\
2.391 \mathrm{LnDbh}+ \\
56.17(1 / \mathrm{Dbh})\end{array}$ & 1 & 1 & 1 & 1 & 4 & 1 \\
\hline $\begin{array}{l}\text { LnB_Tot }= \\
2.728+ \\
1.193 \mathrm{LnDbh}\end{array}$ & 4 & 8 & 4 & 4 & 20 & 4 \\
\hline $\begin{array}{l}\text { LogB_Tot }= \\
1.185^{+} \\
1.193 \operatorname{LogDbh}\end{array}$ & 2 & 8 & 2 & 4 & 16 & 3 \\
\hline $\begin{array}{l}\text { LogB_Tot }= \\
1.153+ \\
1.191 \text { LogDbh }+ \\
\text { o.0177LogLbds }\end{array}$ & 3 & 9 & 5 & 10 & 27 & 7 \\
\hline $\begin{array}{l}\text { LogB_Tot }= \\
1.279+ \\
1.234 \operatorname{LogDBH}- \\
\text { o.113LogH }\end{array}$ & 3 & 10 & 3 & 11 & 27 & 7 \\
\hline
\end{tabular}

Berdasarkan kriteria statistik dari Tabel 5 dapat diamati bahwa persamaan $\log \mathrm{B}_{-}$Tot $=-7.08+$ 2.391LnDbh $+56.17(1 / \mathrm{Dbh})$ mempunyai performansi yang paling baik. Persamaan ini memenuhi syarat uji kriteria persamaan terbaik.

\subsection{Menentukan Besarnya Potensi Biomassa Pohon Cempaka}

Menentukan besarnya potensi biomassa batang dan biomassa total pohon cempaka dalam penelitian ini membutuhkan data diameter setinggi dada (Dbh) pohon baru yang diukur pada petak ukur dengan luas 20om $^{2}$ sebanyak 25 pohon. Data Dbh yang diperoleh antara 18-32 cm. Setelah data Dbh tersedia, maka data tersebut dimasukkan ke persamaan regresi alometrik terpilih untuk menduga besarnya potensi biomassa batang: $\log \mathrm{B}_{\mathrm{btg}}=1.5371+0.721$ LogDbh dan biomassa total $: \log B_{\text {tot }}=-7.08+2.391 \mathrm{LnDbh}+56.17(1 / \mathrm{Dbh})$.

Hasil penjumlahan pendugaan biomassa batang pohon cempaka untuk 25 pohon sebesar 8728.978897 $\mathrm{kg}$. Untuk mengetahui besarnya potensi biomassa batang dalam 1 ha maka dikonversi ke dalam luas 1 ha. Hasil konversinya yaitu 25 petak dikali jumlah dugaan biomassa batang pohon cempaka untuk 25 pohon atau sebesar $\pm 218224.472 \mathrm{~kg}$.

Hasil Penjumlahan pendugaan biomassa total pohon cempaka untuk 25 pohon sebesar 19470.31322 $\mathrm{kg}$. Untuk mengetahui besarnya potensi biomassa total dalam 1 ha maka dikonversi ke dalam luas 1 ha. Hasil konversinya yaitu 25 petak dikali jumlah dugaan biomassa total pohon cepaka untuk 25 pohon atau sebesar $\pm 486757.831 \mathrm{~kg}$.

\section{Penutup}

\subsection{Kesimpulan}

1. Persamaan regresi alometrik terbaik penduga biomassa batang dan biomassa total pohon cempaka hanya terdiri dari satu variabel bebas yaitu variabel diameter setinggi dada (Dbh). Adapun persamaan alometriknya sebagai berikut :
a) Biomassa batang $0.721 \operatorname{LogDbh}$
b) Biomassa total 2.391LnDbh + 56.17(1/Dbh)
$:$ Log $B_{\text {btg }}=1.5371+$ : $\log B_{\text {tot }}=-7.08+$

Besarnya potensi biomassa batang pohon cempaka pada luas 1 ha dengan diameter setinggi dada (dbh) 18-32 cm sebesar $\pm 218224.472 \mathrm{~kg}$ sedangkan besarnya potensi biomassa total pohon cempaka dengan diameter setinggi dada (dbh) 18$32 \mathrm{~cm}$ sebesar $\pm 486757.831 \mathrm{~kg}$.

\subsection{Saran}

Pendugaan biomassa untuk jenis pohon cempaka (Elmerrillia ovalis), model persamaan alometrik batang dan total pohon yang didapatkan dalam penelitian ini cukup valid jika digunakan pada kondisi kisaran data diameter dan umur yang sama.

\section{REFERENSI}

[1] Chapman, V. J. 1976. Mangrove Vegetation. Vaduz, Cramer J. pp: 197.

[2] Brown, S. 1997. Estimating Biomass and Biomass Change of Tropical Forest. A Primer. FAO. Forestry Paper No. 134. USA: FAO. Hlm 10-13.

[3] Whitmore, T. C. 1985. Tropical Rain Forest of The Far East. Oxford University Press. New York.

[4] Ketterings Q. M, Coe R, Noordjwik, M. V, Ambagau,Y., Palm, C. A. 2001. Reducing Uncertainty in the Use of Allometric Biomass Equations for Predicting Above-Ground Tree Biomass in Mixed Secondary Forest. Forest Ecology and Management 146: 199-209.

[5] Langi, Y. A. R. 2007. Model Penduga Biomassa Dan Karbon Pada Tegakan Hutan Rakyat Cempaka (Elmerrillia Ovalis) Dan Wasian (Elmerrrillia Celebica) Di Kabupaten Minahasa Sulawesi Utara. [tesis]. Sekolah Pascasarjana ITB, Bogor.

[6] Undang-Undang RI No. 41 tahun 1999 tentang Kehutanan.

[7] Nair, P. K. R., Editor. 1989. Agroforestry System in Tropics. Dordrecht, The Netherlands: Kluwer Academic Publishers, 245 p.

[8] Nair, P. K. R., Latt Cr, Muschler R, Huettl R, Editor. 1995. Agroforestry in Industrialized Nations. Agroforestry System. Special Issue, 31: 97-198. 


\section{Penentuan Model Persamaan Regresi Alometrik Terbaik Untuk Menduga Biomassa Pohon Cempaka (Elmerrillia ovalis) Di Kecamatan Tareran Kabupaten Minahasa Selatan \\ d’Cartesian : Jurnal Matematika dan Aplikasi, Vol. 8, No. 1 (Maret 2019) : 69 - 75}

[9] Hatidja, D. 2006. Bahan Ajar : Analisis Regresi. Jurusan Matematika FMIPA UNSRAT, Manado.

[10] Niklas, K. J. 1994. Plant allometry : the scaling of form and process. University of Chicago Press, Chicago.

[11] Huxley, J. S. 1993. Problems of relative growth. John Hopkins University Press, London.

[12] Parresol, B. R. 1999. Assessing tree and stand biomass : a review with examples and critical comparisons. Forest Science 45 : 573-593.

[13] Hairiah K, Sitompul SM, Meine van N, Cherly P. 2001. Methods for sampling carbon stock above and below ground. Bogor: ICRAF Southeast Asia.

[14] Krisnawati, H.,Adinugroho, W. C., Imanuddin, R. 2012. Monograf : Model-Model Alometrik untuk Pendugaan Biomassa Pohon pada Berbagai Tipe Ekosistem Hutan di Indonesia. Pusat Penelitian dan Pengembangan Konservasi dan Rehabilitasi, Badan Penelitian dan Pengembangan Kehutanan, Bogor.

[15] Possu, W. B. 2015. Carbon Storage Potential of Windbreaks on Agricultural Lands of the Continental United States. Disertation \& Theses in Natural Resources. Paper 117.

Wandy Tato' Appi' (wandytatoappi2@gmail.com)

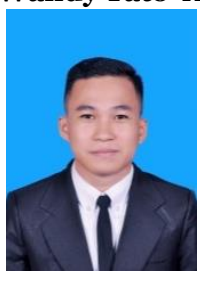
Lahir di Karua, Sulawesi Selatan pada tanggal $\quad 25 \quad$ November 1996. Menempuh pendidikan tinggi Jurusan Matematika, FMIPA, Universitas Sam Ratulangi Manado. Tahun 2018 adalah tahun terakhir ia menempuh studi. Makalah ini merupakan hasil penelitian skripsinya yang

dipublikasikan.

Mans L. Mananohas (mansmananohas.unsrat.ac.id)

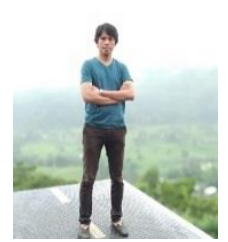

Pada tahun 2006, memperoleh gelar sarjana di Program Studi Matematika, Universitas Sam Ratulangi. Gelar Magister Sains diperoleh dari Institut Teknologi Bandung pada tahun 2013. Menjadi dosen di Jurusan Matematika, FMIPA, Universitas Sam Ratulangi Manado sejak tahun 2009 sampai sekarang dengan bidang keahlian yang ditekuni diantaranya; Analisis dan Aljabar

Yohanes A. R. Langi (yarlangi@gmail.com)

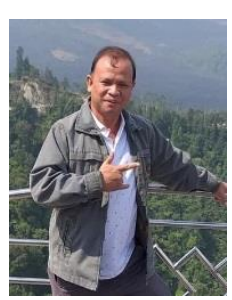

Lahir di Jakarta pada tanggal 13 Juni 1970. Pada tahun 1994 mendapatkan gelar Sarjana Sains (S.Si) yang diperoleh dari Universitas Kristen Indonesia - Tomohon. Gelar Master Sains (M.Si) diperoleh dari Institut Pertanian Bogor pada tahun 2007. Ia bekerja di UNSRAT di Program Studi Matematika sebagai pengajar akademik tetap UNSRAT. 